\title{
Bovine liver slices combined with an androgen transcriptional activation assay: an in-vitro model to study the metabolism and bioactivity of steroids
}

\author{
S. Wang - J. C. W. Rijk • J. H. Riethoff-Poortman • \\ S. Van Kuijk • A. A. C. M. Peijnenburg • T. F. H. Bovee
}

Received: 21 December 2009/Revised: 18 February 2010 /Accepted: 19 February 2010 /Published online: 17 March 2010

(C) The Author(s) 2010. This article is published with open access at Springerlink.com

\begin{abstract}
Previously we described the properties of a rapid and robust yeast androgen bioassay for detection of androgenic anabolic compounds, validated it, and showed its added value for several practical applications. However, biotransformation of potent steroids into inactive metabolites, or vice versa, is not included in this screening assay. Within this context, animal-friendly in-vitro cellular systems resembling species-specific metabolism can be of value. We therefore investigated the metabolic capacity of precision-cut slices of bovine liver using $17 \beta$-testosterone $(\mathrm{T})$ as a model compound, because this is an established standard compound for assessing the metabolic capacity of such cellular systems. However, this is the first time that slice metabolism has been combined with bioactivity measurements. Moreover, this study also involves bioactivation of inactive prohormones, for example dehydroepiandrosterone (DHEA) and esters of $\mathrm{T}$, and although medium extracts are normally analyzed by HPLC, here the metabolites formed were identified with more certainty by ultra-performance liquid chromatography time-of-flight mass spectrometry (UPLCTOFMS) with accurate mass measurement. Metabolism of $\mathrm{T}$ resulted mainly in the formation of the less potent phase I metabolites 4-androstene-3,17-dione (4-AD), the hydroxyT metabolites $6 \alpha, 6 \beta, 15 \beta$, and $16 \alpha-\mathrm{OH}-\mathrm{T}$, and the phase II metabolite T-glucuronide. As a consequence the overall
\end{abstract}

S. Wang · J. C. W. Rijk · J. H. Riethoff-Poortman · S. Van Kuijk • A. A. C. M. Peijnenburg

RIKILT - Institute of Food Safety, Wageningen UR,

P.O. Box 230, 6700 AE Wageningen, The Netherlands

T. F. H. Bovee $(\square)$

RIKILT - Institute of Food Safety, Wageningen UR,

Akkermaalsbos 2,

6708 WB Wageningen, The Netherlands

e-mail: toine.bovee@wur.nl androgenic activity, as determined by the yeast androgen bioassay, decreased. In order to address the usefulness of bovine liver slices for activation of inactive steroids, liver slices were exposed to DHEA and two esters of T. This resulted in an increase of androgenic activity, because of the formation of 4-AD and $\mathrm{T}$.

Keywords Bovine liver slices · Mass spectrometry · Metabolism $\cdot$ Histology $\cdot$ Yeast androgen bioassay

\section{Introduction}

Food and feed for humans and animals may contain residues of contaminants. Many of these chemical residues for example pesticides, heavy metals, and dioxins are believed to have detrimental effects. Maximum residue limits (MRLs) have therefore been established by the European Commission, and minimum required performance limits (MRPLs) for forbidden substances. Regulatory authorities carry out extensive monitoring and surveillance programs in order to ensure consumer safety. Monitoring today is still mainly carried out by chemical analytical methods, but bioassay screening has been shown to be complementary and is thus a valuable tool [1]. The main advantages of bioassay-activitybased methods are that they are easy, cost-effective, and, most importantly, able to detect unknown or new compounds that are, consequently, absent from the chemist's reference set. Their main disadvantages are that they cannot establish the identity of a compound and are often unable to detect compounds that require metabolic activation. The latter problem can be overcome by introduction of a bioactivation step.

Biotransformation involves phase I and phase II pathways and mainly takes place in the liver and intestine $[2,3]$. 
Phase I is usually oxidative and these reactions are mainly catalyzed by the different enzymes of the cytochrome P450 (CYP) supergene family. In phase II, such oxidized moieties are conjugated with highly polar molecules, mainly glucuronic acid or sulfate. Both phases are responsible for detoxification and rendering lipophilic molecules more polar and more readily excreted. Several in-vitro models are currently used to study the metabolism of compounds. These range from simple enzyme preparations, specifically S9 fractions, microsomes, and supersomes, to whole cell systems, for example primary cell cultures, transformed cell lines, and tissue slices. All these models have their specific advantages and disadvantages and were well reviewed by Plant in 2004 and by Coecke et al. in 2006 [4, 5]. The main advantages of whole-cell systems is that they include the induction of drugmetabolizing enzymes and drug transporters. However, human-derived cell lines, for example Caco-2 and LS180, do not express all drug-metabolizing enzymes and transporters present in the small intestine and colon [6-8]. Hepatotoxicity and liver metabolism are most often studied with freshly isolated rat hepatocytes or the human liver HepG2 cell line. Although successful, rat hepatocytes do not adequately predict the human in-vivo metabolism, and gene expression patterns in human HepG2 cells strongly depend on the manner of cultivation $[9,10]$. Moreover, during hepatocyte isolation there is a loss of cytochrome P450 activity, which can partly be overcome by addition of collagen or dexamethasone or by co-culture with overlaying endothelial cells $[11,12]$. However, there are indications that Kupffer and Ito cells in liver affect metabolism and slow the decrease of cytochrome P450 enzyme activity [13]. Thus, use of precision-cut liver slices has the advantage that all liver cell types are present and maintain their original interactions and spatial arrangement. Moreover, collagen and all phase I and phase II enzymes are present together with natural amounts of cofactors such as ATP, NADPH, NADP, and $\mathrm{Mg}^{2+}$ [14]. Precision-cut liver slices have been used successfully in a variety of studies. Van de Bovenkamp et al. used human liver slices to study the development of liver fibrosis and Salonen et al. studied the metabolic clearance of selegiline, a drug used to treat patients suffering from Parkinson disease [15-17]. Zalko et al. and De La Torre et al. used bovine liver slices to study the metabolism of clenbuterol and conjugated linoleic acid (CLA), respectively $[18,19]$.

Here we used $17 \beta$-testosterone $(\mathrm{T})$ and the prohormone dehydroepiandrosterone (DHEA), a steroid precursor of $\mathrm{T}$ that does not have hormonal activity by itself, and studied their metabolic fate in bovine liver slices. Incubated extracts were analyzed by ultra-performance liquid chromatography time-of-flight mass spectrometry (UPLC-TOFMS) with accurate mass measurement and screened for bioactivity with a highly androgen-specific yeast bioassay. The main objectives were to investigate whether both phase I and phase II enzymes were active in liver cells of slices and whether slices could thus be used as an in-vitro model to mimic the in-vivo metabolic deactivation of $\mathrm{T}$ and activation of DHEA. We also investigated whether this deactivation and activation could be monitored with a yeast androgen transcriptional activation assay and this latter possibility was further explored with the inactive testosterone esters T-acetate and T-decanoate.

\section{Materials and methods}

\section{Chemicals}

4-Androstene-3,17-dione (4-AD), $2 \alpha, 6 \alpha, 6 \beta, 7 \alpha, 11 \alpha$, $11 \beta, 15 \beta$, and $16 \alpha$-hydroxytestosterone, and $17 \beta$ testosterone $(\mathrm{T})$ were obtained from Steraloids (Newport, RI, USA). Testosterone glucuronide was obtained from LGC Standards (Teddington, UK). Sodium hydrogen carbonate, D-(+)-glucose, Titriplex III (EDTA), tris(hydroxymethyl)aminomethane (Tris), calcium chloride dehydrate, potassium chloride, sodium chloride, magnesium sulfate heptahydrate, potassium dihydrogen phosphate, and dimethyl sulfoxide (DMSO) were purchased from Merck (Darmstadt, Germany). Williams' medium E supplemented with Glutamax I (WE) and charcoal-stripped foetal bovine serum (csFBS) were obtained from Gibco/Invitrogen (Breda, The Netherlands). Acetonitrile, methanol, and diethyl ether were from Biosolve (Valkenswaard, The Netherlands). Dextrose and yeast nitrogen base without amino acids and without ammonium sulfate were from Difco (Detroit, MI, USA), and dehydroepiandrosterone (DHEA), L-Leucine, bovine serum albumin (BSA), and HEPES were purchased from Sigma (St Louis, MO, USA). Water used for UPLC-TOFMS was purified using a Millipore (Bedford, MA, USA) Milli-Q system.

\section{Preparation of liver slices}

Bovine liver from male cattle $(350-550 \mathrm{~kg}, 1.5-2.5$ years old) was purchased at the local slaughterhouse. Immediately after the animals were killed the caudate liver lobe was excised and flushed with ice-cold Krebs-Henseleit buffer (pH 7.4) containing $10 \mathrm{mmol} \mathrm{L}^{-1}$ HEPES and $25 \mathrm{mmol} \mathrm{L}^{-1}$ glucose. Liver tissue was stored in ice-cold KrebsHenseleit buffer and transported to the laboratory within $30 \mathrm{~min}$. Cylindrical cores of liver were produced using a stainless steel tube and a drill press. Cores were immediately placed in ice-cold oxygenated Williams' medium E with Glutamax I (WE) supplemented with $25 \mathrm{mmol} \mathrm{L}^{-1}$ glucose and 10\% csFBS. A Krumdieck tissue slicer 
(Alabama Research and Development, Munford, AL, USA) filled with ice-cold WE was used to produce precision-cut slices with a diameter of $8 \mathrm{~mm}$ and a thickness of $0.25 \mathrm{~mm}$. Immediately after preparation, slices were stored in ice-cold WE and only the most uniformly shaped slices were selected for incubation experiments. Each slice weighted approximately $27 \mathrm{mg}$ and contained approximately $2 \mathrm{mg}$ protein.

\section{Liver slice incubations}

Bovine liver slices were incubated in six-well culture plates. Each well contained $3.2 \mathrm{~mL}$ prewarmed $\mathrm{WE}$ supplemented with $25 \mathrm{mmol} \mathrm{L}^{-1}$ D-glucose and $10 \%$ csFBS. Culture plates containing the liver slices were incubated in a shaking water bath (90 rpm) under carbogen atmosphere $\left(95 \% \mathrm{O}_{2} / 5 \% \mathrm{CO}_{2}\right)$ at $37{ }^{\circ} \mathrm{C}$. To study the metabolizing capacity of bovine liver slices, $16 \mu \mathrm{L}$ testosterone or DHEA stock solutions in DMSO were added to WE medium (final concentration $10-250 \mu \mathrm{mol} \mathrm{L}^{-1}$ ). For each concentration incubation was performed in triplicate, with and without slices, for $6 \mathrm{~h}$. Control incubations of liver slices were performed with $16 \mu \mathrm{L}$ DMSO for $0,2,4$, or $6 \mathrm{~h}$. After incubation, media were frozen and stored at $-20{ }^{\circ} \mathrm{C}$ until analysis by UPLC-TOFMS and a yeast androgen bioassay. For ATP measurements, slices were transferred into $1 \mathrm{~mL}$ sonication solution containing $70 \%$ ethanol and $2 \mathrm{mmol} \mathrm{L}{ }^{-1}$ EDTA, rapidly frozen in liquid nitrogen, and stored at $-80{ }^{\circ} \mathrm{C}$ until assayed. For histological evaluation, slices were fixed in $4 \%$ buffered formaldehyde.

\section{ATP measurement}

To determine slice viability, ATP levels were measured as described by De Kanter et al. in 2004 [20]. After thawing, slices were homogenized by sonication and centrifuged at $13,000 \mathrm{rpm}$ for $2 \mathrm{~min}$. The supernatant was diluted 10 times with $0.1 \mathrm{~mol} \mathrm{~L}^{-1}$ Tris- $\mathrm{HCl} / 2 \mathrm{mmol} \mathrm{L}{ }^{-1}$ EDTA solution buffer to lower the ethanol concentration. The ATP content was measured using a CLSII ATP bioluminescence assay kit from Roche (Mannheim, Germany). Protein content of liver slices were determined according to Lowry et al. [21], using the BioRad DC protein assay (BioRad, Veenendaal, The Netherlands) and BSA as standard. ATP determination was performed in triplicate and results are expressed as pmol ATP $\mathrm{mg}^{-1}$ protein.

\section{Histology}

Immediately after incubation, slices were fixed in $4 \%$ buffered formaldehyde. After embedding in paraffin, cross-sections were prepared, stained with haematoxylin and eosin using standard procedures, and examined under a microscope [22].
Extraction procedure

Samples of medium were thawed at room temperature. Aliquots of $3.2 \mathrm{~mL}$ medium were mixed with $6 \mathrm{~mL}$ diethyl ether and shaken head over head for $10 \mathrm{~min}$. Samples were sonicated for $2 \mathrm{~min}$ in an ultrasonic bath and subsequently centrifuged at $3,000 \mathrm{~g}$ for $5 \mathrm{~min}$. The supernatant was transferred to a glass tube and the residue was extracted again with $3 \mathrm{~mL}$ diethyl ether. The combined organic phase was evaporated until dryness under a gentle stream of nitrogen gas and reconstituted in $1.5 \mathrm{~mL}$ acetonitrile before screening for androgenic activity with a yeast androgen bioassay. For HPLC analysis, samples of medium were sometimes spiked with $10 \mu \mathrm{g} \mathrm{mL}^{-1} 11 \beta-\mathrm{OH}-\mathrm{T}$ as internal standard to generate controls and extracted with diethyl ether as described above. The extract was evaporated under a stream of $\mathrm{N}_{2}$ gas, reconstituted in $0.3 \mathrm{~mL}$ acetonitrilewater $(10: 90, v / v)$, and $50 \mu \mathrm{L}$ was injected into the HPLC system. For UPLC-TOFMS analysis, $3.2 \mathrm{~mL}$ medium was subjected to solid-phase extraction (SPE) on an Oasis Max column (3 cc (60 mg) LP Extraction cartridges from Waters Corporation, Milford, Massachusetts, USA) previously conditioned with $6 \mathrm{~mL}$ methanol and $6 \mathrm{~mL}$ water. Subsequently, the column was washed with $6 \mathrm{~mL}$ water buffered with $2 \%$ formic acid. The column was air-dried and eluted with $5 \mathrm{~mL}$ methanol. The eluate was evaporated under a stream of $\mathrm{N}_{2}$ gas and reconstituted in $0.3 \mathrm{~mL}$ acetonitrile-water $(10: 90, v / v), 50 \mu \mathrm{L}$ was injected into the UPLC-TOFMS system.

\section{HPLC analysis}

HPLC analysis was performed on a Waters HPLC System (Waters Millipore; Milford, MA) consisting of Model 510 and 515 pumps, Model 717 plus auto injector, and an automated gradient controller. Analytical separations were carried out on a Symmetry C18 Column $(5 \mu \mathrm{m}, 3.0 \times$ $150 \mathrm{~mm}$ ) at $40{ }^{\circ} \mathrm{C}$. The mobile phases consisted of (A) water-acetonitrile $(90: 10 \mathrm{v} / \mathrm{v})$ and (B) HPLC-grade acetonitrile. Gradient elution was applied at a flow rate of $1 \mathrm{~mL} \mathrm{~min}^{-1}$, starting at $10 \% \mathrm{~B}$ and linearly programmed to $75 \% \mathrm{~B}$ in $30 \mathrm{~min}$. Next, the gradient remained $5 \mathrm{~min}$ at $75 \% \mathrm{~B}$ and returned linearly in $5 \mathrm{~min}$ to the initial conditions. The effluent was monitored at a wavelength of $247 \mathrm{~nm}$ with a Waters 996 photodiode-array detector. Stock solutions of T, 4-AD, and hydroxylated testosterone standards $\left(1 \mathrm{mg} \mathrm{mL}^{-1}\right)$ were prepared in acetonitrile and an equal volume of each was used to prepare standard mixtures of $10 \mu \mathrm{g} \mathrm{mL}^{-1}$. Replicate injections $(n=10)$ of the standard mixtures and individual standards were analyzed to determine the variability of the retention time, peak area, and peak height. Metabolites were determined by comparison of their retention times using authentic standards. 


\section{UPLC-TOFMS analysis}

Ultra-performance liquid chromatography (UPLC) was performed on a Waters (Milford, MA, USA) Acquity system containing a Waters Acquity UPLC BEH C18 $(1.7 \mu \mathrm{m}, 2.1 \times$ $150 \mathrm{~mm}$ ) column with mobile phases (A) acetonitrile-waterformic acid (10:90:0.2, v/v) and (B) acetonitrile-waterformic acid (90:10:0.2, v/v) at a flow rate of $0.4 \mathrm{~mL} \mathrm{~min}^{-1}$. After an isocratic period of $2 \mathrm{~min}$ at $15 \% \mathrm{~B}$, the gradient increased linearly to $70 \% \mathrm{~B}$. The gradient then remained at $70 \% \mathrm{~B}$ for $2 \mathrm{~min}$ and was restored to the initial conditions in $2 \mathrm{~min}$. The column temperature was set at $40{ }^{\circ} \mathrm{C}$ and the injection volume was $50 \mu \mathrm{L}$. Before mass spectrometry the column effluent was split 1:1.

Mass spectrometry was performed on a Waters Micromass (Manchester, UK) model LCT premier MS system equipped with a dual electrospray ionization (ESI) probe. The system was operated in positive-ion mode (ESI+) at a source temperature of $120{ }^{\circ} \mathrm{C}$, desolvation temperature $400{ }^{\circ} \mathrm{C}$, desolvation gas flow $500 \mathrm{~L} \mathrm{~h}^{-1}$, capillary voltage $2500 \mathrm{~V}$, and a cone voltage of $50 \mathrm{~V}$. Phosphoric acid in acetonitrile-water $(0.01: 50: 50 \mathrm{v} / \mathrm{v})$ was used as a lock mass calibrant and introduced via the second ESI probe at a flow rate of $10 \mu \mathrm{L} \mathrm{min}{ }^{-1}$. Data were collected between $\mathrm{m} / \mathrm{z} 80$ and 1000 and processed using Masslynx v 4.1 software (Waters).

\section{Androgenic activity measurement}

Extracts in acetonitrile $(200 \mu \mathrm{L})$ were transferred to a Vshaped 96-well plate in triplicate and $50 \mu \mathrm{L}$ of a $4 \%$ DMSO solution was added to each well. To remove acetonitrile the plate was dried overnight in a fume cupboard and the remaining extract was dissolved in only $2 \mu \mathrm{L}$ DMSO the next day. Aliquots of undiluted sample extracts were also investigated with $\mathrm{T}$ spikes. These extracts spiked after extraction were prepared by addition of $2 \mu \mathrm{L} 30 \mu \mathrm{mol} \mathrm{L}^{-1} \mathrm{~T}$ stock, resulting in a final concentration of $300 \mathrm{nmol} \mathrm{L}^{-1}$ in the well after adding $200 \mu \mathrm{L}$ of the yeast culture. In the same way and in each separate experiment a medium blank and corresponding spikes were prepared and used as negative and positive controls. The yeast androgenic activity measurement has been described in detail before, because this assay was fully validated according to EC guidelines, and subsequently also accredited ISO 17025 , for the determination of androgenic activity in animal feed and urine [23]. In short: a single colony of the yeast androgen bioassay was taken from a minimal medium agar plate with L-leucine $(\mathrm{MM} / \mathrm{L})$ and used to inoculate $10 \mathrm{~mL}$ selective liquid $\mathrm{MM} / \mathrm{L}$ medium. This culture was grown overnight at $30{ }^{\circ} \mathrm{C}$ with vigorous orbital shaking. At the late log phase, the yeast $A R$ cytosensor was diluted in selective $\mathrm{MM} / \mathrm{L}$ medium to an $\mathrm{OD}$ value at $630 \mathrm{~nm}$ between 0.04 and 0.06 . For exposure to standard compounds, aliquots of $200 \mu \mathrm{L}$ of this diluted yeast culture were pipetted into each well of a 96-well plate and $2 \mu \mathrm{L}$ T stock solutions or other compounds in DMSO were added. DMSO and $\mathrm{T}$ controls were included in each experiment and each sample concentration was assayed in triplicate. For exposure of yeast to sample extracts, $200 \mu \mathrm{L}$ aliquots of diluted yeast culture were pipetted into each well already containing the dried extracts as described above. Exposure was performed for $24 \mathrm{~h}$ at $30^{\circ} \mathrm{C}$ and orbital shaking at $125 \mathrm{rpm}$. Fluorescence and optical density (OD) were measured at 0 and $24 \mathrm{~h}$ in a Synergy HT Multi-Detection Microplate Reader (BioTek Instruments, USA) using excitation at $485 \mathrm{~nm}$ and emission at $530 \mathrm{~nm}$. The fluorescence signal was corrected with the signals obtained with $\mathrm{MM} / \mathrm{L}$ medium containing DMSO solvent only. After incubating for $24 \mathrm{~h}$, the OD at $630 \mathrm{~nm}$ was determined to check whether the yeast had grown well or if a sample was toxic.

\section{Results}

\section{ATP level}

To assess the usefulness of ATP measurements as a tool to determine the viability of slices, slices were not only incubated with $\mathrm{T}$ and DHEA, but also with toxic reference compounds. ATP levels were measured immediately after preparation of the slices and after incubation for 2, 4 and $6 \mathrm{~h}$. Figure 1A shows that bovine liver slices remained viable in the six-well plate incubation system for at least $6 \mathrm{~h}$. However, the ATP level was relatively low immediately after slicing and increased to a maximum at $4 \mathrm{~h}\left(1.0 \mathrm{pmol} \mathrm{\mu g}^{-1}\right.$ protein). This is most probably because of temperature differences, as the liver was transported on ice, sliced at low temperatures with cold buffers, and then incubated at $37^{\circ} \mathrm{C}$. After $6 \mathrm{~h}$ the ATP level in the cultured slice was approximately $90 \%$ of the maximum. The maximum ATP level obtained with the bovine liver slices is lower than that of rat liver slices incubated under the same conditions. The latter reached levels of $2-5 \mathrm{pmol} \mathrm{\mu g}^{-1}$ protein (data not shown). However, this difference may be because of the dissimilarity of the hepatic energy status between ruminants and rats, but could also be caused by less than optimum conditions for the bovine liver during dissection.

The effect of addition of known toxic substances, for example cycloheximide (CH), sodium azide (SA), and sodium dodecyl sulfate (SDS), on ATP content is shown in Fig. 1B. The ATP level was significantly reduced by $50 \mu \mathrm{g} \mathrm{mL}$ sodium dodecyl sulfate $\left(170 \mu \mathrm{mol} \mathrm{L}{ }^{-1} \mathrm{SDS}\right)$ and heating the slices for $10 \mathrm{~min}$ at $75{ }^{\circ} \mathrm{C}$. Remarkably, the ATP level was only slightly reduced by $50 \mu \mathrm{g} \mathrm{mL} \mathrm{m}^{-1}$ cycloheximide $\left(170 \mu \mathrm{mol} \mathrm{L}{ }^{-1}\right)$ and sodium azide $\left(760 \mu \mathrm{mol} \mathrm{L}{ }^{-1}\right)$, but both compounds at $5 \mathrm{mg} \mathrm{mL}^{-1}$ doses significantly reduced the ATP level. Addition of T or DHEA up to $100 \mu \mathrm{mol} \mathrm{L}{ }^{-1}$ did not affect the ATP level compared with the control. 


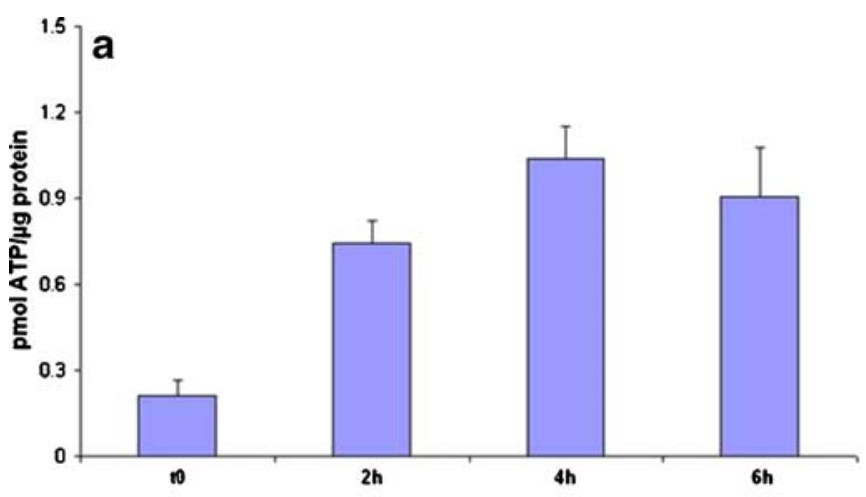

Fig. 1 ATP measurements of exposed bovine liver slices. ATP levels in bovine liver slices (A) after different incubation intervals in the presence of $0.5 \%$ DMSO and (B) after $6 \mathrm{~h}$ incubation with cycloheximide $(\mathrm{CH})$, sodium azide $(\mathrm{SA})$, sodium dodecyl sulfate

\section{Histology}

The bovine liver slices were examined for histological differences in order to further explore effects on viability.

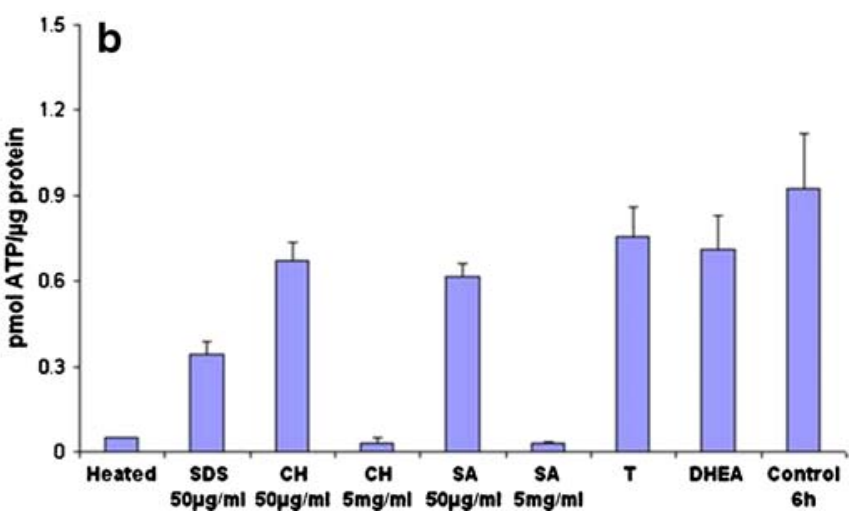

$(S D S), 17 \beta$-testosterone $(T)$, or DHEA. Negative controls for viability of the slices were prepared by heating for $10 \mathrm{~min}$ at $75^{\circ} \mathrm{C}$. Each value is the mean \pm SEM from three to five independent experiments and expressed as pmol ATP $\mu \mathrm{g}^{-1}$ protein

Control liver slices showed normal architecture of the liver, with a preserved trabecular structure of parenchyma cells (Fig. 2A). The structure of slices exposed to $100 \mu \mathrm{mol} \mathrm{L}{ }^{-1}$ $\mathrm{T}$ was very similar to that of control slices. The lobular
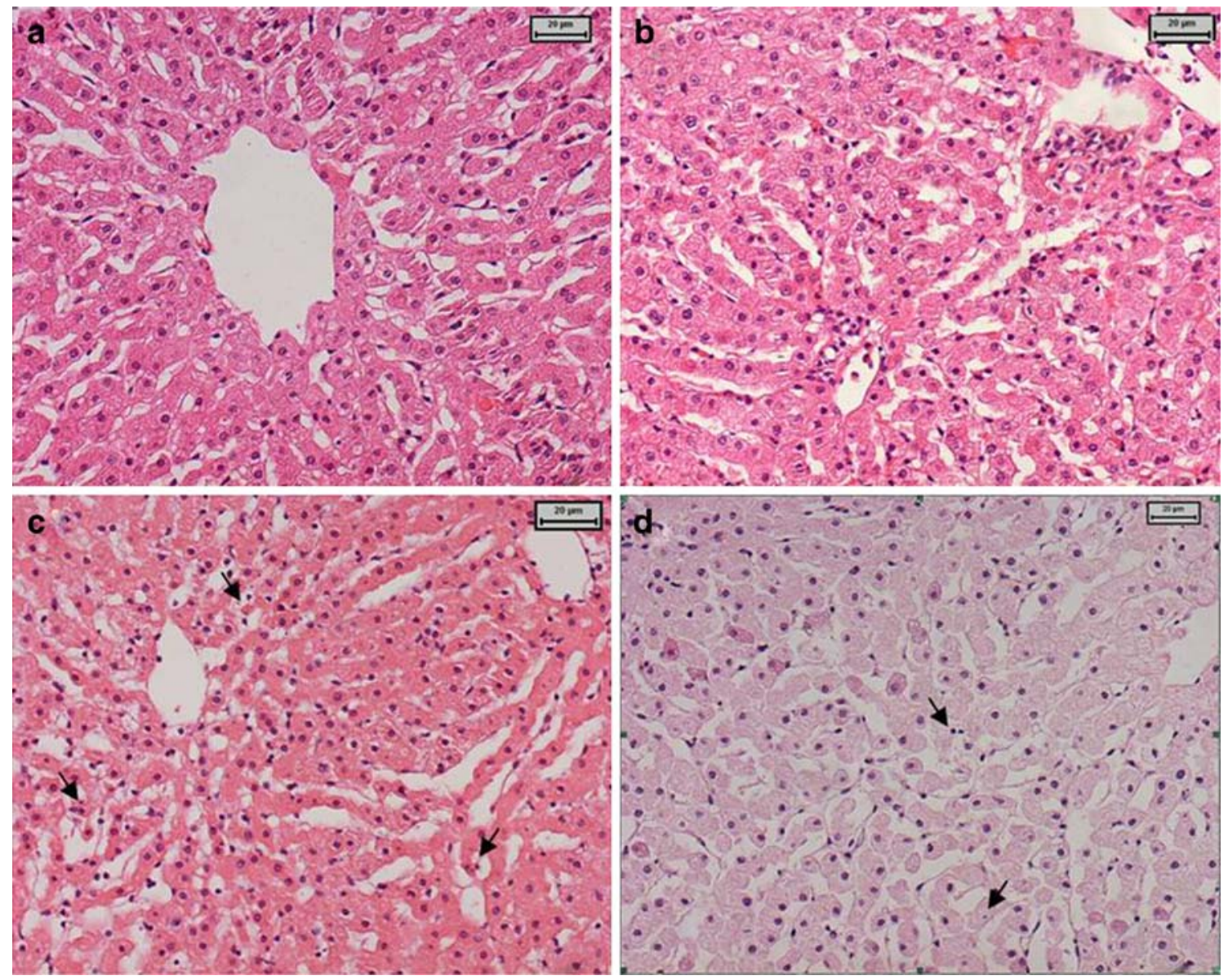

Fig. 2 Effect of added chemicals on the histology of cultured bovine liver slices. Haematoxylin and eosin-stained slices after $6 \mathrm{~h}$ of culture with (A) $0.5 \%$ DMSO, (B) $100 \mu \mathrm{mol} \mathrm{L} \mathrm{L}^{-1} \mathrm{~T}$, (C) $50 \mu \mathrm{g} \mathrm{mL}$

cycloheximide, and (D) $50 \mu \mathrm{g} \mathrm{mL}^{-1}$ SDS. The figures are representative of at least three separate experiments. Bars indicate a length of $20 \mu \mathrm{m}$. Arrows indicate necrosis of hepatocytes 
pattern was easily recognizable, with central vein and periportal triads. The nuclei with nucleoli were clearly visible as in normal cells (Fig. 2B). Slices exposed to $100 \mu \mathrm{mol} \mathrm{L}{ }^{-1}$ DHEA were also very similar to the control (data not shown).

Figure $2 \mathrm{C}$ shows a photomicrograph of a bovine liver slice exposed to $50 \mu \mathrm{g} \mathrm{mL} \mathrm{m}^{-1}$ cycloheximide. Liver architecture was maintained with few changes, minimal single-hepatocyte necrosis was seen (arrows), sinusoids were slightly dilated, and most hepatocytes had a normal appearance and the trabecular pattern was preserved. Also, exposure to $50 \mu \mathrm{g} \mathrm{mL}^{-1}$ sodium azide did not result in a clear histological change (data not shown), but Fig. 2D shows that the cell architecture was severely damaged by $50 \mu \mathrm{g} \mathrm{mL}^{-1} \mathrm{SDS}$, with loss of the trabecular pattern, reduced eosinophilic staining of the cytoplasm, and degraded or condensed nuclei (arrows).

\section{HPLC and UPLC-TOFMS analysis}

The metabolites in extracts of medium were analyzed by HPLC to investigate the metabolic capacity of bovine liver slices. A set of reference compounds, based on known metabolites and the biosynthesis of steroids, was chosen. Van het Klooster et al., for instance, showed the formation of $2 \beta, 6 \beta, 11 \alpha, 12 \beta$, and $16 \alpha-\mathrm{OH}-\mathrm{T}$ when bovine hepatocyte cultures were exposed to $\mathrm{T}$ [24]. Based on retention time comparison, HPLC analysis of medium extracts obtained from incubations of bovine liver slices with $100 \mu \mathrm{mol} \mathrm{L}{ }^{-1}$ $\mathrm{T}$ for $6 \mathrm{~h}$ indicated the formation of 4-AD, $6 \beta-\mathrm{OH}-\mathrm{T}$, and $11 \alpha-\mathrm{OH}-\mathrm{T}$ and small amounts of $2 \alpha-\mathrm{OH}-\mathrm{T}, 11 \beta-\mathrm{OH}-\mathrm{T}$, $15 \beta-\mathrm{OH}-\mathrm{T}$, and $16 \alpha-\mathrm{OH}-\mathrm{T}$. From the reference set, only the $6 \alpha-\mathrm{OH}-\mathrm{T}$ could not be determined as a metabolite formed after the slices had been exposed to T. In addition, the HPLC profile showed a number of additional metabolites. These results are summarized in Table 1.

UPLC-TOFMS analysis was then used to identify some of these metabolites with more certainty. The UPLCTOFMS ion chromatograms are presented in Fig. 3. This figure shows that some of the major oxidation products of $\mathrm{T}$ formed could be identified as the hydroxy metabolites $6 \alpha$ $\mathrm{OH}-\mathrm{T}$, $6 \beta-\mathrm{OH}-\mathrm{T}$, and $15 \beta-\mathrm{OH}-\mathrm{T}$ (Fig. 3A) and as 4-AD and T-17-D-glucuronide (Fig. 3B). These TOFMS results are also summarized in Table 1. In contrast with HPLC

Table 1 HPLC and UPLC-TOFMS analysis data for extracts of medium in which bovine liver slices were incubated for $6 \mathrm{~h}$ with testosterone

\begin{tabular}{|c|c|c|c|c|c|c|}
\hline \multicolumn{2}{|l|}{ HPLC analysis } & \multicolumn{5}{|c|}{ UPLC-TOFMS analysis } \\
\hline Retention time $(\min )^{\mathrm{a}}$ & Possible metabolite ${ }^{\mathrm{a}}$ & & Retention time $(\mathrm{min})^{\mathrm{b}}$ & Experimental mass ${ }^{\mathrm{c}}$ & Empirical formula & Identified metabolite $^{\mathrm{d}}$ \\
\hline 8.28 & $15 \beta-\mathrm{OH}-\mathrm{T}$ & I & 6.27 & $305.2091(-2.6)$ & $\mathrm{C}_{19} \mathrm{H}_{29} \mathrm{O}_{3}$ & $15 ß-\mathrm{OH}-\mathrm{T}$ \\
\hline $8.54(6 \alpha-\mathrm{OH}-\mathrm{T})$ & $\mathrm{Np}$ & II & 6.35 & $305.2092(-2.5)$ & $\mathrm{C}_{19} \mathrm{H}_{29} \mathrm{O}_{3}$ & $6 \alpha-\mathrm{OH}-\mathrm{T}$ \\
\hline 9.81 & $6 ß-\mathrm{OH}-\mathrm{T}$ & III & 6.74 & $305.2092(-2.5)$ & $\mathrm{C}_{19} \mathrm{H}_{29} \mathrm{O}_{3}$ & $6 ß-\mathrm{OH}-\mathrm{T}$ \\
\hline 10.39 & $?$ & IV & 6.98 & $305.2090(-2.7)$ & $\mathrm{C}_{19} \mathrm{H}_{29} \mathrm{O}_{3}$ & $?$ \\
\hline \multirow[t]{2}{*}{12.39} & $16 \alpha-\mathrm{OH}-\mathrm{T}$ & $\mathrm{V}$ & 7.49 & $305.2078(-3.9)$ & $\mathrm{C}_{19} \mathrm{H}_{29} \mathrm{O}_{3}$ & $16 \alpha-\mathrm{OH}-\mathrm{T}$ \\
\hline & & VI & 7.61 & $305.2131(1.4)$ & $\mathrm{C}_{19} \mathrm{H}_{29} \mathrm{O}_{3}$ & $?$ \\
\hline 13.05 & $11 \alpha-\mathrm{OH}-\mathrm{T}$ & $\begin{array}{l}11 \alpha-\mathrm{OH}- \\
\mathrm{T}\end{array}$ & 7.83 & 305.2135 & $\mathrm{C}_{19} \mathrm{H}_{29} \mathrm{O}_{3}$ & $\mathrm{~Np}$ \\
\hline 13.42 & $?$ & VII & 8.10 & $305.2075(-4.2)$ & $\mathrm{C}_{19} \mathrm{H}_{29} \mathrm{O}_{3}$ & $?$ \\
\hline 13.73 & $?$ & & & & & \\
\hline 13.94 & $?$ & & & & & \\
\hline 14.74 & $11 \beta-\mathrm{OH}-\mathrm{T}$ & VIII & 8.25 & $305.2095(-2.2)$ & $\mathrm{C}_{19} \mathrm{H}_{29} \mathrm{O}_{3}$ & $?$ \\
\hline 14.98 & $?$ & IX & 8.29 & $465.2476(-1.2)$ & $\mathrm{C}_{25} \mathrm{H}_{37} \mathrm{O}_{8}$ & T-Gluc \\
\hline 15.19 & $?$ & & & & & \\
\hline 16.25 & $2 \alpha-\mathrm{OH}-\mathrm{T}$ & $2 \alpha-\mathrm{OH}-\mathrm{T}$ & 8.9 & 305.2139 & $\mathrm{C}_{19} \mathrm{H}_{29} \mathrm{O}_{3}$ & $\mathrm{~Np}$ \\
\hline 17.01 & $?$ & $\mathrm{X}$ & 9.03 & $305.2080(-3.7)$ & $\mathrm{C}_{19} \mathrm{H}_{29} \mathrm{O}_{3}$ & $?$ \\
\hline 19.20 & $?$ & XI & 9.59 & $465.2455(-3.3)$ & $\mathrm{C}_{25} \mathrm{H}_{37} \mathrm{O}_{8}$ & $?$ \\
\hline 20.05 & $17 \beta-\mathrm{T}$ & XII & 11.04 & $289.2156(-1.2)$ & $\mathrm{C}_{19} \mathrm{H}_{29} \mathrm{O}_{2}$ & $17 \beta-\mathrm{T}$ \\
\hline 21.18 & $4-\mathrm{AD}$ & XIII & 11.79 & $287.2023(1.2)$ & $\mathrm{C}_{19} \mathrm{H}_{27} \mathrm{O}_{2}$ & 4-AD \\
\hline
\end{tabular}

$\mathrm{Np}=$ not present

${ }^{a}$ Experimental retention time and possible metabolite by comparison of the retention time with those of standards in HPLC

${ }^{\mathrm{b}}$ Experimental retention times (UPLC-TOFMS)

${ }^{c}$ Accurate masses of observed ions, with mass error versus the theoretical masses in $\mathrm{mDa}$ (in parentheses)

${ }^{\mathrm{d}}$ Compounds confirmed by retention time comparison with a standard (UPLC-TOFMS) 
Fig. 3 UPLC-TOFMS mass chromatograms. UPLC-TOFMS reconstructed accurate-mass chromatograms for (A) $\mathrm{m} / \mathrm{z} 305.2117$ and $(\mathbf{B}) \mathrm{m} / \mathrm{z}$ $287.2011+\mathrm{m} / \mathrm{z} 289.2168+\mathrm{m} / \mathrm{z}$ 465.2488 after incubation of bovine liver slices with $100 \mu \mathrm{mol} \mathrm{L}{ }^{-1} \mathrm{~T}$ for $6 \mathrm{~h}$, and $(\mathbf{C})$ $\mathrm{m} / \mathrm{z} 305.2117$ after co-exposure of liver slices to $100 \mu \mathrm{mol} \mathrm{L}{ }^{-1} \mathrm{~T}$ and $50 \mu \mathrm{g} \mathrm{mL}^{-1}$ cycloheximide
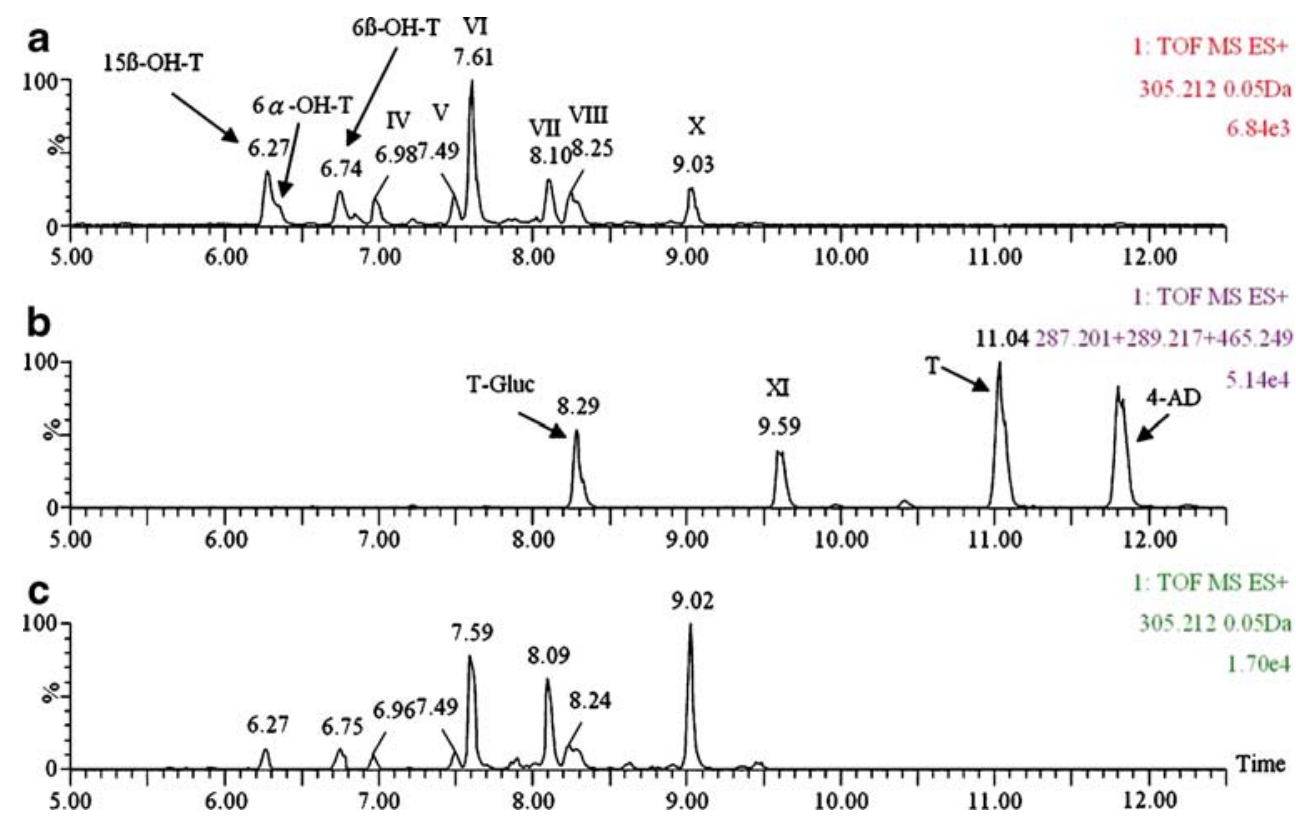

analysis, this shows that $6 \alpha-\mathrm{OH}-\mathrm{T}$ was formed but formation of $2 \alpha-\mathrm{OH}-\mathrm{T}$ and $11 \alpha-\mathrm{OH}-\mathrm{T}$ could not be confirmed. The formation of $11 \beta-\mathrm{OH}-\mathrm{T}$ could not be confirmed by TOFMS, because this compound was used as an internal standard.

When liver slices were exposed to DHEA, the HPLC analysis revealed the formation of mainly $4-\mathrm{AD}$ and $11 \alpha-\mathrm{OH}-\mathrm{T}$ and minor amounts of $15 \beta-\mathrm{OH}-\mathrm{T}$ and $16 \alpha-\mathrm{OH}-\mathrm{T}$. The formation of 4-AD was confirmed by TOFMS (data not shown).

When liver slices were exposed to T or DHEA in the presence of $50 \mu \mathrm{g} \mathrm{mL} \mathrm{mL}^{-1}$ cycloheximide, the HPLC or TOFMS metabolite profiles were identical with that after exposure to T or DHEA alone. Figure 3C shows the profile of the hydroxy metabolites of $\mathrm{T}$ when liver slices were exposed to $\mathrm{T}$ in the presence of $50 \mu \mathrm{g} \mathrm{mL}^{-1}$ cycloheximide. Because the metabolite profile in Fig. $3 \mathrm{C}$ is identical with that of Fig. 3A, these results show that $50 \mu \mathrm{g} \mathrm{mL}$ cycloheximide has no effect on the metabolism of $\mathrm{T}$. Similar results were obtained with sodium azide (data not shown).

\section{Androgenic activity measurement}

Figure 4 shows the dose-response curves of $\mathrm{T}$ and several hydroxy metabolites of $\mathrm{T}$ in the yeast androgen bioassay; the results are summarized in Table 2. These show that the hydroxy metabolites of $\mathrm{T}$ are, relatively, much less potent than $4-\mathrm{AD}$ and T. The $2 \alpha-\mathrm{OH}-\mathrm{T}$ and $11 \alpha-\mathrm{OH}-\mathrm{T}$ are the most potent hydroxy metabolites of $\mathrm{T}$ and are about 100 and 300 times less potent, respectively, than T; whereas $7 \alpha$ $\mathrm{OH}-\mathrm{T}, 11 \beta-\mathrm{OH}-\mathrm{T}$, and $15 \beta-\mathrm{OH}-\mathrm{T}$ are moderately active, $6 \alpha-\mathrm{OH}-\mathrm{T}$ and $6 \beta-\mathrm{OH}-\mathrm{T}$ are almost inactive, and $16 \alpha-\mathrm{OH}-\mathrm{T}$ is not active in the yeast androgen bioassay.
Medium extracts were prepared after exposure of slices to $\mathrm{T}$ and DHEA and subsequently screened in the yeast androgen bioassay. Figure 5A shows the responses of extracts of medium in which slices were exposed to T. After 1000-fold dilution, the response of the control incubation, i.e. without slices, is still near maximum, whereas the response for $\mathrm{T}$ incubated with slices is reduced. Assuming no metabolism and no recovery loss during the extraction procedure, the undiluted extract and the 1000-fold diluted $\mathrm{T}$ extracts would theoretically result in well concentrations of $78 \mu \mathrm{mol} \mathrm{L}^{-1}$ and $78 \mathrm{nmol} \mathrm{L}^{-1} \mathrm{~T}$, respectively. According to a $\mathrm{T}$ dose-response curve, $78 \mathrm{nmol} \mathrm{L}^{-1}$ would still give a

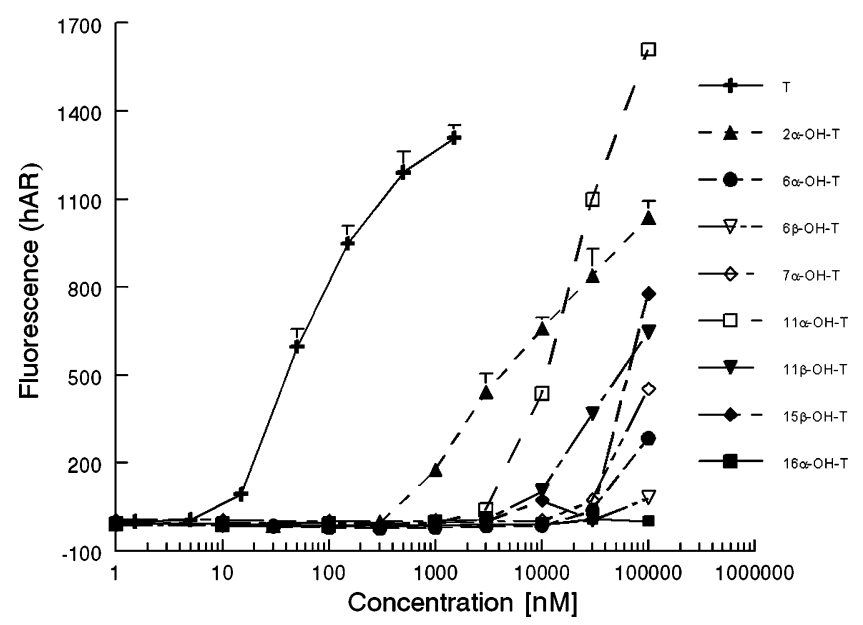

Fig. 4 Response of seven different hydroxy metabolites of $\mathrm{T}$ in the yeast androgen bioassay. Exposure to $17 \beta$-testosterone $(\mathrm{T})$ and hydroxy metabolites of $\mathrm{T}$ was started by adding $2 \mu \mathrm{L}$ aliquots of stock solutions of the compound in DMSO to $200 \mu \mathrm{L}$ yeast culture in a 96-well plate. Fluorescence was determined after $24 \mathrm{~h}$. Fluorescence signals are means from triplicate measurements, with SD 
Table $2 \mathrm{EC}_{50}$ concentrations and relative androgenic potencies (RAP) of compounds in the RIKILT yeast androgen bioassay expressing yEGFP in response to androgens

\begin{tabular}{|c|c|c|}
\hline Compound & $\begin{array}{l}\mathrm{EC}_{50}\left(\mathrm{nmolL}^{-1}\right) \\
\text { in the } \mathrm{RAA}^{\mathrm{a}}\end{array}$ & $\mathrm{RAP}^{\mathrm{b}}$ \\
\hline $17 \beta$-Testosterone $(17 \beta-T)^{\mathrm{c}}$ & $40-80^{\mathrm{f}}$ & 1.0 \\
\hline $17 \alpha$-Testosterone $(17 \alpha-T)^{\mathrm{c}}$ & n.r. & n.r. \\
\hline $5 \alpha$-Dihydrotestosterone $(5 \alpha \text {-DHT })^{\mathrm{c}}$ & 33 & 2.3 \\
\hline Androsterone $^{c}$ & n.r. & n.r. \\
\hline 4-Androstenedione $(4-\mathrm{AD})^{\mathrm{c}, \mathrm{e}}$ & $7.2 \mathrm{E} 3$ & 0.011 \\
\hline Dehydroepiandrosterone $\left(\right.$ DHEA) ${ }^{\mathrm{c}}$ & n.r. & n.r. \\
\hline $2 \alpha$-Hydroxytestosterone $(2 \alpha-\mathrm{OH}-\mathrm{T})^{\mathrm{d}}$ & $5.6 \mathrm{E} 3$ & 0.011 \\
\hline $6 \alpha$-Hydroxytestosterone $(6 \alpha-\mathrm{OH}-\mathrm{T})^{\mathrm{d}}$ & n.r. & n.r. \\
\hline $6 \beta$-Hydroxytestosterone $(6 \beta-\mathrm{OH}-\mathrm{T})^{\mathrm{d}}$ & n.r. & n.r. \\
\hline $7 \alpha$-Hydroxytestosterone $(7 \alpha-\mathrm{OH}-\mathrm{T})^{\mathrm{d}}$ & $8.6 \mathrm{E} 4$ & $7.4 \mathrm{E}-4$ \\
\hline $11 \alpha$-Hydroxytestosterone $(11 \alpha-\mathrm{OH}-\mathrm{T})^{\mathrm{d}}$ & $2.1 \mathrm{E} 4$ & $3.0 \mathrm{E}-3$ \\
\hline $11 \beta$-Hydroxytestosterone $(11 \beta-\mathrm{OH}-\mathrm{T})^{\mathrm{d}}$ & $3.0 \mathrm{E} 4$ & $2.2 \mathrm{E}-3$ \\
\hline $15 \beta$-Hydroxytestosterone $(15 \beta-\mathrm{OH}-\mathrm{T})^{\mathrm{d}}$ & $1.6 \mathrm{E} 5$ & $4.0 \mathrm{E}-4$ \\
\hline $16 \alpha$-Hydroxytestosterone $(16 \alpha-\mathrm{OH}-\mathrm{T})^{\mathrm{d}}$ & n.r. & n.r. \\
\hline Testosterone-17-D-glucuronide (T-Gluc) ${ }^{\mathrm{d}}$ & n.r. & n.r. \\
\hline $17 \beta$-Estradiol $(17 \beta \text {-E2 })^{\mathrm{c}}$ & $9.0 \mathrm{E} 3$ & $8.4 \mathrm{E}-3$ \\
\hline Progesterone $\mathrm{e}^{\mathrm{c}, \mathrm{e}}$ & $1.7 \mathrm{E} 3$ & 0.045 \\
\hline Dexamethasone $^{c}$ & n.r. & n.r. \\
\hline
\end{tabular}

n.r. $=$ no response.

${ }^{\mathrm{a}}$ The $\mathrm{EC}_{50}$ is the concentration giving half-maximum response

${ }^{b}$ The relative androgenic potency (RAP) is defined as the ratio between the $\mathrm{EC}_{50}$ of $17 \beta-\mathrm{T}$ and the $\mathrm{EC}_{50}$ of the compound

${ }^{\mathrm{c}}$ Obtained by Bovee et al. [35] in an experiment in which the $\mathrm{EC}_{50}$ for $17 \beta$-T was $76 \mathrm{nmol} \mathrm{L}^{-1}$

${ }^{\mathrm{d}}$ RAPs were calculated from an $\mathrm{EC}_{50}$ for $17 \beta-\mathrm{T}$ of $64 \mathrm{nmol} \mathrm{L}{ }^{-1}$

${ }^{\mathrm{e}}$ The maximum responses obtained with 4 -androstenedione and progesterone, respectively, were approximately 50 and $35 \%$ of that of $17 \beta-\mathrm{T}$

${ }^{\mathrm{f}} \mathrm{The}$ range in the $\mathrm{EC}_{50}$ of $17 \beta-\mathrm{T}$ in different experiments is, in general, between 40 and $80 \mathrm{nmol} \mathrm{L}^{-1}$

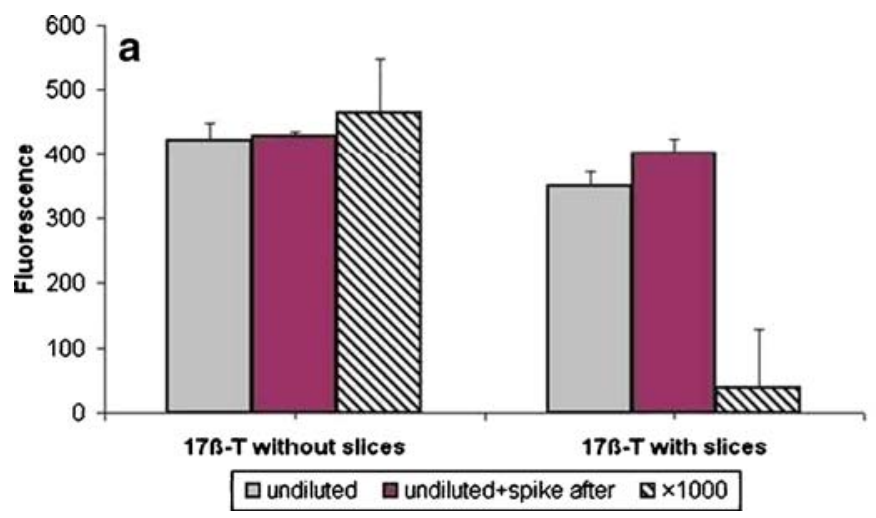

Fig. 5 Androgen bioassay responses of bovine liver slices exposed to $\mathrm{T}$ and DHEA. Androgen bioassay responses of (A) $100 \mu \mathrm{mol} \mathrm{L} \mathrm{L}^{-1}$ $17 \beta$-testosterone $(17 \beta-T)$ and (B) $100 \mu \mathrm{mol} \mathrm{L} \mathrm{L}^{-1}$ DHEA incubated for $6 \mathrm{~h}$ with or without bovine liver slices. Undiluted medium extracts maximum response. The drop in the response in the 1000 -fold diluted extract of $\mathrm{T}$ that was incubated with liver slices, points in the direction of metabolism of $\mathrm{T}$ into less androgen-active or to androgen-inactive metabolites. This is in agreement with the data obtained by metabolite identification by HPLC and UPLC-TOFMS, showing that $\mathrm{T}$ was metabolized into less or no active T-metabolites. Moreover, both methods show that the capacity of these bovine liver slices to metabolize $\mathrm{T}$ is relatively low, because the drop in the androgenic response was only observed in the 1000-fold diluted extract and, besides many metabolites, the UPLC-TOFMS analysis still showed a very large $T$ peak (Fig. 3B).

The androgen assay showed no signal for a control incubation of DHEA $\left(100 \mu \mathrm{mol} \mathrm{L}{ }^{-1}\right)$ without liver slices, but after metabolic activation of DHEA by the bovine slices, a maximum fluorescence response was obtained in the yeast androgen bioassay (Fig. 5B). The signal was still visible in the tenfold diluted extract. Because DHEA itself does not show a response in the yeast androgen bioassay, the signal obtained is probably because of formation of the androgen-active metabolites 4-AD and $\mathrm{T}$.

Positive controls, i.e. undiluted extracts spiked afterwards with $\mathrm{T}$, resulted in a final concentration of $300 \mathrm{nmol} \mathrm{L} \mathrm{L}^{-1} \mathrm{~T}$ in the well, which would, theoretically, give a maximum response (black bars in Fig. 5). These "spike-after" controls were performed in order to investigate whether sample extracts contain disturbing or inhibiting compounds. Figure 5B shows that only the positive DHEA control without slices did not give a maximum response, which means that the response of $\mathrm{T}$ in this extract is inhibited. This inhibiting effect can be explained by the antagonistic properties of DHEA, because it was demonstrated in a previous study that DHEA is not an AR agonist, but acts as an AR antagonist $[25,26]$. Figure 5B also shows that DHEA was activated by liver slices. Moreover, the

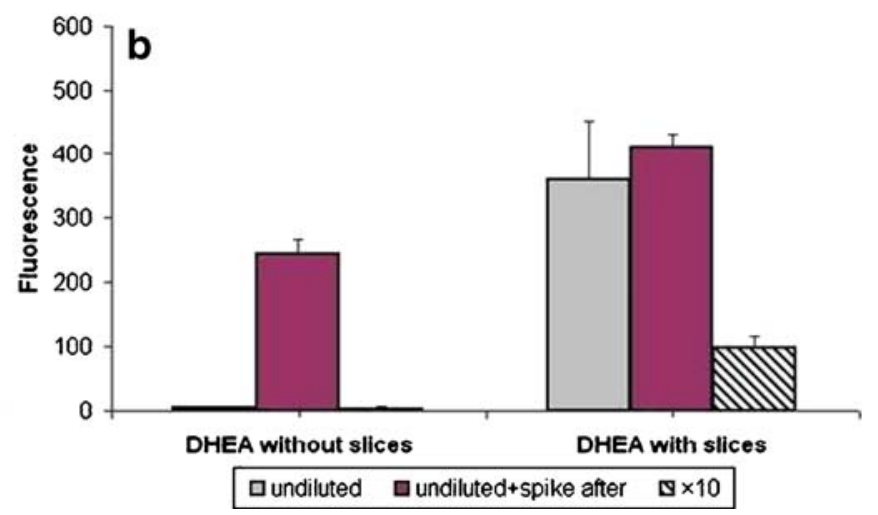

were spiked with $2 \mu \mathrm{L} 30 \mu \mathrm{mol} \mathrm{L} \mathrm{L}^{-1} 17 \beta$-testosterone in the well. Fluorescence was determined after $24 \mathrm{~h}$ and signals are means from triplicate measurements, with SD 
antagonistic response in the positive DHEA control with slices disappeared, once more demonstrating that DHEA was converted into more agonistic metabolites causing a positive response in the yeast androgen bioassay.

In addition to DHEA, two testosterone esters were investigated in the slice model in order to further demonstrate that slices can be used as a model to mimic the in-vivo activation of inactive hormone precursors and can subsequently be detected in a bioassay. According to HPLC analysis, both T-acetate and T-decanoate were rapidly converted into $\mathrm{T}$ (data not shown) and a clear increase of androgenic activity was observed in the bioassay. The latter is shown in Fig. 6 for T-decanoate.

\section{Discussion}

ATP content is generally regarded as a sensitive indicator of a slice's viability, but convincing data are limited [3]. The usefulness of ATP measurements was more thoroughly investigated in this study. Slices exposed to $100 \mu \mathrm{mol} \mathrm{L}{ }^{-1}$ $\mathrm{T}$ or DHEA did not affect ATP levels compared with the control, whereas slices exposed to the toxic reference compounds cycloheximide $(\mathrm{CH})$, sodium azide (SA), and sodium dodecyl sulfate (SDS), or heating the slices for $10 \mathrm{~min}$ at $75^{\circ} \mathrm{C}$, significantly reduced the ATP levels, although relatively high concentrations of $\mathrm{CH}$ and SA were needed. SA is a highly toxic substance, but its mechanism of toxicity has not been fully established. It binds to $\mathrm{Fe}^{3+}$ in cytochrome oxidase in mitochondria and inhibits the respiratory chain by cancelling oxidative phosphorylation [27]. In a study with different human cell lines the concentration at which sodium azide inhibited metabolic activity, measured by a decrease in oxygen consumption, was lower in nerve and myocardial cells than in fibroblasts, hepatocytes, and renal tubular epithelial cells [28]. That

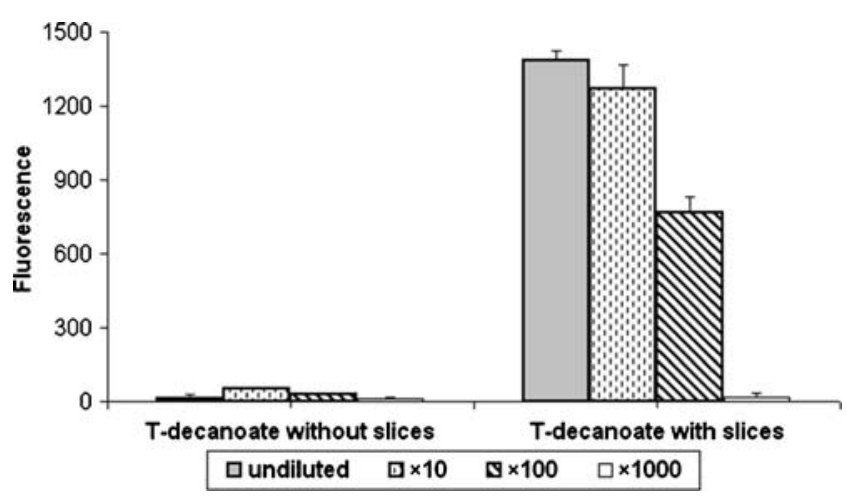

Fig. 6 Androgen bioassay responses of bovine liver slices exposed to $\mathrm{T}$-decanoate. Androgen bioassay responses of $100 \mu \mathrm{mol} \mathrm{L}^{-1} \mathrm{~T}$ decanoate incubated for $6 \mathrm{~h}$ with or without bovine liver slices. Fluorescence was determined after $24 \mathrm{~h}$ and signals are means from triplicate measurements, with SD study showed a clear effect on oxygen consumption at concentrations of $10 \mu \mathrm{g} \mathrm{mL}^{-1}$ in the more sensitive nerve and myocardial cells, whereas here there is a small effect on the ATP level in liver cells at a dose of $50 \mu \mathrm{g} \mathrm{mL}^{-1}$ and a clear effect with $5 \mathrm{mg} \mathrm{mL}^{-1}$. Cycloheximide is an inhibitor of protein synthesis, and Smith et al. reported that $10 \mu \mathrm{mol} \mathrm{L}{ }^{-1} \mathrm{CH}$ rapidly inhibited protein synthesis and secretion in rat liver slices, but did not affect intracellular $\mathrm{K}^{+}$and did not induce LDH leakage [29]. Thus, although this protein synthesis inhibitor might affect the metabolic capacity of the liver cells, especially the activity of cytochromes $\mathrm{P} 450$ phase I enzymes, it is not expected that cycloheximide in the $\mu \mathrm{mol} \mathrm{L}^{-1}$ range will induce $\mathrm{LDH}$ leakage or a decrease in ATP levels. On the other hand, many studies have shown that long-time exposure to this concentration leads to cell death. SDS is a surfactant and is used in cosmetic products such as soaps, shampoos, and tooth paste. It can lead to direct damage to the hair follicle, skin damage, permanent eye damage, and even liver toxicity [30]. In male Wistar rats treated once a day with $25 \mathrm{mg} \mathrm{SDS} \mathrm{kg}{ }^{-1}$ for three days, the cytochrome P-450 content of the liver was reduced by $24 \%$, indicating that SDS affects the metabolic capacity [31]. SDS already showed a clear effect on the ATP level at $50 \mu \mathrm{g} \mathrm{mL}^{-1}$. As a surfactant SDS is also a membrane disruptor and the drop in the ATP level of exposed liver slices was thus as expected.

The outcomes of the histological observations were all in agreement with the assessment of the ATP content, showing no or minimum effects with $100 \mu \mathrm{mol} \mathrm{L}^{-1} \mathrm{~T}$ and DHEA or low concentrations of $\mathrm{CH}$ and SA. Moreover, when liver slices were exposed to $\mathrm{T}$ or DHEA in the presence of $50 \mu \mathrm{g} \mathrm{mL}^{-1} \mathrm{CH}$ or SA, the HPLC or TOFMS metabolite profiles were identical with that obtained after exposure to $\mathrm{T}$ or DHEA alone. The cell architecture was severely damaged by $50 \mu \mathrm{g} \mathrm{mL}^{-1} \mathrm{SDS}$, with loss of the trabecular pattern, reduced eosinophilic staining of the cytoplasm, and degraded or condensed nuclei. SDS at $50 \mu \mathrm{g} \mathrm{mL}^{-1}$ also had a clear effect on the ATP level. These results prove that measurement of the ATP level is a reliable means of assessing both the viability and metabolic capacity of liver slice cells.

The metabolites identified, $6 \alpha-\mathrm{OH}-\mathrm{T}, 6 \beta-\mathrm{OH}-\mathrm{T}, 15 \beta-$ $\mathrm{OH}-\mathrm{T}$, and 4-AD, after exposure of bovine liver slices to $\mathrm{T}$ prove that phase I enzymes are active, and the formation of T-17-D-glucuronide proves the activity of at least one phase II pathway. With regard to exposure of bovine liver slices to DHEA (in similar experiments but using slices obtained from different animals), we were able to detect not only 4-AD, $11 \alpha$ $\mathrm{OH}-\mathrm{T}, 15 \beta-\mathrm{OH}-\mathrm{T}$, and $16 \alpha-\mathrm{OH}-\mathrm{T}$ but, frequently, small amounts of $\mathrm{T}$ also. The formation of both 4-AD and $\mathrm{T}$ is in line with a previous study, using a bovine liver S9 mix with NAD for metabolic bioactivation of DHEA, showing the formation of 4-AD, T, and $7 \alpha-\mathrm{OH}-\mathrm{DHEA}$ [32]. 
It has previously been shown that $\mathrm{T}$ is a potent compound in the yeast androgen bioassay, whereas DHEA is a prohormone that is not active in this bioassay [25, 32]. These studies have also shown that some phase I metabolites, for example 4-AD, $5 \alpha$-androstane- $3 \beta, 17 \beta$ diol, $5 \alpha$-androstane- $3 \alpha \beta, 17 \beta$-diol, and $5 \alpha$-androstane$17 \beta$-ol-3-one (better known as $5 \alpha$-DHT), are active, although less potent than $\mathrm{T}$, in this yeast androgen bioassay, whereas others, for example $17 \alpha$-testosterone and androsterone, are not active. However, hydroxy metabolites of $\mathrm{T}$ have not yet been tested. Here it is shown that the hydroxy metabolites of $\mathrm{T}$ are, relatively, much less potent in the yeast androgen bioassay than $\mathrm{T}$ and $4-\mathrm{AD}$. The $2 \alpha-\mathrm{OH}-\mathrm{T}$ and $11 \alpha-\mathrm{OH}-\mathrm{T}$ are the most potent hydroxy metabolites of $\mathrm{T}$ and are about 100 and 300 times less potent, respectively, than $\mathrm{T}$, whereas $7 \alpha-\mathrm{OH}-\mathrm{T}, 11 \beta-\mathrm{OH}-\mathrm{T}$, and $15 \beta-\mathrm{OH}-\mathrm{T}$ are moderately active, $6 \alpha-\mathrm{OH}-\mathrm{T}$ and $6 \beta-\mathrm{OH}-\mathrm{T}$ are almost inactive, and $16 \alpha-\mathrm{OH}-\mathrm{T}$ is not active.

With regard to the metabolism of the model compound $\mathrm{T}$ with bovine liver slices in combination with androgen activity measurements using the yeast bioassay, the formation of several hydroxy metabolites of T, 4-AD, and T-17D-glucuronide not only proves that both phase I and phase II enzymes are active in bovine liver slices, but in line with the formation of these less active metabolites, a clear decrease of androgenic activity was observed. Moreover, the conversion of the prohormone DHEA into active metabolites like 4-AD and $\mathrm{T}$ resulted in a clear increase of the androgenic activity as measured in the yeast androgen bioassay. Also, the bioactivation of T-acetate and T-decanoate, shown by the formation of $\mathrm{T}$ and an increase of androgenic activity as determined by the yeast bioassay, shows that bovine liver slices can be used for the conversion of inactive prohormones and indicates that the liver slices contain esterase activity.

In conclusion, liver slices can serve as an adequate invitro model to study the species-specific metabolism of steroids in liver and can be used as a complementary tool for screening for biologically inactive steroids. Moreover, application of liver slice models can reduce the use of laboratory animals, because liver tissue can be easily obtained from the slaughterhouse.

Acknowledgements This project was financially supported by the Dutch Ministry of Agriculture, Nature, and Food Quality (project number 872468.01). We thank Rob Bakker and Jan Ossenkoppele for their technical assistance with the histology examination and Maria Groot for interpretation of the histology examination.

Open Access This article is distributed under the terms of the Creative Commons Attribution Noncommercial License which permits any noncommercial use, distribution, and reproduction in any medium, provided the original author(s) and source are credited.

\section{References}

1. Bovee TFH, Pikkemaat MG (2009) Bioactivity-based screening of antibiotics and hormones. J Chromatogr A 1216:8035-8050

2. Van der Kerkhof EG, Ungell AB, Sjoberg AK, De Jager MH, Hilgendorf C, De Graaf IAM, Groothuis GMM (2006) Innovative methods to study human intestinal drug metabolism in vitro: precision-cut slices compared with Ussing Chamber preparations. Drug Metab Dispos 34:1893-1902

3. Van der Kerkhof EG, De Graaf IA, De Jager MH, Groothuis GM (2007) Induction of phase I and II drug metabolism in rat small intestine and colon in vitro. Drug Metab Dispos 35:898-907

4. Plant N (2004) Strategies for using in vitro screens in drug metabolism. Drug discov today 9:328-336

5. Coecke S et al (2006) Metabolism: A bottleneck in in vitro toxicological test development. The report and recommendations of ECVAM Workshop 54. ATLA 34:49-84

6. Taipalensuu J, Törnblom H, Lindberg G, Einarsson C, Sjöqvist F, Melhus H, Garberg P, Sjöström B, Lundgren B, Artursson P (2001) Correlation of gene expression of ten efflux proteins of the ATP-binding cassette transporter family in normal human jejunum and in human intestinal epithelial Caco-2 cell monolayers. Pharmacology 229:164-170

7. Sun D, Lennernas H, Welage LS, Barnett JL, Landowski CP, Foster D, Fleisher D, Lee KD, Amidon GL (2002) Comparison of human duodenum and Caco-2 gene expression profiles for 12 , 000 gene sequences tags and correlation with permeability of 26 drugs. Pharm Res 19:1400-1416

8. Fricker G, Miller DS (2002) Relevance of multidrug resistance proteins for intestinal drug absorption in vitro and in vivo. Pharmacol Toxicol 90:5-13

9. Waring JF, Ciurlionis R, Jolly RA, Heindel M, Gagne G, Fagerland JA, Ulrich RG (2003) Isolated human hepatocytes in culture display markedly different gene expression patterns depending on attachment status. Toxicol In Vitro 17:693-701

10. Richart L, Liguori MJ, Abadie C, Heyd B, Mantion G, Halkic N, Waring JF (2006) Gene expression in human hepatocytes in suspension after isolation is similar to the liver of origin, is not affected by hepatocyte cold storage and cryopreservation, but is strongly changed after hepatocyte plating. Drug Metab Dispos 34:870-879

11. Harimoto M, Yamato M, Hirose M, Takahashi C, Isoi Y, Kikuchi A, Okano T (2002) Novel approach for achieving double-layered cell sheets co-culture: overlaying endothelial cell sheets onto monolayer hepatocytes utilizing temperature-responsive culture dishes. J Biomed Mater Res 62:464-470

12. Weiss TS, Jahn B, Cetto M, Jauch KW, Thasler WE (2002) Collagen sandwich culture affects intracellular polyamine levels of human hepatocytes. Cell Prolif 35:257-267

13. Pagliara P, Carla EC, Caforio S, Chionna A, Massa S, Abbro C, Dini L (2003) Kupffer cells promote lead nitrate-induced hepatocyte apoptosis via oxidative stress. Comp Hepatol 2:8-21

14. Groothuis GMM (2005) De darm: meer dan absorptie alleen. Pharm weekbl 10:328-331

15. Van de Bovenkamp M, Groothuis GGM, Meijer DKF, Slooff MJH, Olinga P (2006) Human liver slices as an in vitro model to study toxicity-induced hepatic stellate cell activation in a multicellular milieu. Chem Biol Interact 162:62-69

16. Van de Bovenkamp M, Groothuis GGM, Meijer DKF, Olinga P (2007) Liver fibrosis in vitro: cell culture models and precisioncut liver slices. Toxicol In Vitro 21:545-557

17. Salonen JS et al (2003) Comparative studies on the cytochrome $\mathrm{P} 450$-associated metabolism and interaction potential of selegiline between human liver-derived in vitro systems. Drug Metab Dispos 31:1093-1102 
18. Zalko D, Perdu-Durand E, Debrauwer L, Bec-Ferte MP, Tulliez J (1998) Comparative metabolism of clenbuterol by rat and bovine liver microsomes and slices. Drug Metab Dispos 26:28-35

19. De La Torre A, Gruffat D, Chardigny JM, Sebedio JL, Durand D, Loreau O, Bauchart D (2005) In vitro metabolism of rumenic acid in bovine liver slices. Reprod Nutr Dev 45:441-451

20. De Kanter R, Monshouwer M, Draaisma AL, De Jager MH, De Graaf IA, Proost JH, Meijer DK, Groothuis GM (2004) Prediction of whole-body metabolic clearance of drugs through the combined use of slices from rat liver, lung, kidney, small intestine and colon. Xenobiotica 34:229-241

21. Lowry OH, Rosebrough NJ, Farr AL, Randall RJ (1951) Protein measurement with the folin phenol reagent. J Biol Chem 193:265-275

22. Groot MJ, Ossenkoppele JS, Bakker R, Pfaffl MW, Meyer HDD, Nielen MWF (2007) Reference histology of veal calf genital and endocrine tissues; an update for screening on hormonal growth promoters. J Vet Med A 53:1-9

23. Bovee TFH, Bor G, Heskamp HH, Lasaroms JJP, Sanders MB, Nielen MWF (2009) Validation and application of a yeast bioassay for screening androgenic activity in calf urine and feed. Anal Chim Acta 637:225-234

24. Van het Klooster GA, Blaauboer BJ, Noordhoek J, Van Miert AS (1993) Cytochrome P450 induction and metabolism of alkoxyresorufins, ethylmorphine and testosterone in cultured hepatocytes from goats, sheep and cattle. Biochem Pharmacol 46:1781-1790
25. Bovee TFH, Helsdingen JR, Hamers ARM, Van Duursen MBM, Nielen MWF, Hoogenboom LAP (2007) A new highly specific and robust yeast androgen biosassay for the detection of agonist and antagonists. Anal Bioanal Chem 389:1549-1558

26. Bovee TFH, Lommerse JPM, Peijnenburg AACM, Antunes Fernandes E, Nielen MWF (2008) A new highly androgen specific yeast biosensor, enabling optimisation of (Q)SAR model approaches. JSBMB 108:121-131

27. Olson KR (1999) Poisoning and drug overdose. Appleton \& Lange 3:99-101

28. Ischikawa T, Zhu B-L, Maeda H (2006) Effect of sodium azide on the metabolic activity of cultured foetal cells. Toxicol Ind Health 22:337-341

29. Smith PF, Fisher R, Shubat PJ, Gandolfi AJ, Krumdieck CL, Brendel $\mathrm{K}$ (1987) In vito cytotoxicity of allyl alcohol and bromobenzene in a novel organ culture system. Toxicol Appl Pharmacol 87:509-522

30. OECD, SIDS Initial assessment profile of Sodium Dodecyl Sulfate, CAS No: 151-21-3.

31. Miura Y (1987) Effects of in vivo administration of detergents on the hepatic microsomal cytochrome P-450 system in rat. J Appl Toxicol 7:213-217

32. Rijk JCW, Bovee TFH, Groot MJ, Peijnenburg AACM, Nielen MWF (2008) Evidence of the indirect hormonal activity of prohormones using liver S9 metabolic bioactivation and an androgen bioassay. Anal Bioanal Chem 392:417-425 